\title{
Population dynamics and parasitation of planktonic and epibenthic crustaceans in the Baltic Schlei fjord
}

\author{
S. Gollasch \& C. D. Zander \\ Zoologisches Institut und Zoologisches Museum der Universität Hamburg; \\ Martin-Luther-King-Platz 3, D-20146 Hamburg, Germany
}

\begin{abstract}
The planktonic and epibenthic crustacean fauna from two sites of the brackish Schlei fjord, Northern Germany, was investigated over a six-month period. Calanoid and cyclopoid copepods were more abundant in lower salinities, whereas benthic decapods, isopods and amphipods prevailed in the site of higher salinity. Cestodan larvae were found only in spring which may be due to the timing of the respective life-cycles. Parasites of benthic crustaceans, mostly digenean metacercariae but also cestodans, acanthocephalans and nematodes, appeared from spring to late summer. Decreasing salinities caused lower intensities of the most abundant parasite, Maritrema subdolum; only the true brackish-water species among the hosts were more heavily infested than those found in higher salinities. The correlation of parasite size and host size at infestation became apparent. Therefore, Crangon crangon is an optimal host for the large Podocotyle atomon metacercariae. Coevolutive trends between some hosts and parasites are made evident.
\end{abstract}

\section{INTRODUCTION}

Crustaceans are very important links in the pelagic as well as in the benthic food chains. Particularly smaller species which are mostly herbivorous are the main prey for young or small-sized fishes (Berg, 1979; Zander, 1979; Schmidt-Moser \& Westphal, 1981; Zander \& Döring, 1989; Zander \& Westphal, 1992). Additionally, many crustacean species turned out to be carriers of fish, bird and mammal parasites which use this group as first or second intermediate hosts (Reimer, 1970). Therefore, crustaceans can be important transfer organisms of helminths within the latter's complicated life-cycle which often involves host alternations (Odening, 1974; Reimer, 1983). There is still, however, a lack of ecological literature on crustacean parasites (MacKenzie \& Gibson, 1970; Wendland, 1985; Lauckner, 1992).

The Baltic Sea is a brackish sea with decreasing salinities from west to east. Whereas the central Baltic presents a wide area with only $0.8-0.6 \%$ salinities which means the area of species minimum in the sense of Remane (1958), some fjords such as the Schlei in northern Schleswig-Holstein (Germany) show a continuous decrease (Nellen, 1967; Schriever, 1974). According to the law of Thienemann (1939), the number of species is low in extreme habitats, but that of individuals is high.

The question is, therefore, whether the populations of parasites behave in the same way as those of their hosts. In order to solve this problem, the structure and dynamics of crustacean populations from two sites with different salinities are compared: the one lying in the $\alpha$-mesohaline zone, the other in the $\beta$-mesohaline zone which corresponds to 
the species minimum. Additionally, the investigations follow the parasite community concept of Esch et al. (1990), according to which the lowest level - the infracommunity is treated with respect to infestation intensities of crustacean parasites.

\section{INVESTIGATION SITE, MATERIAL AND METHODS}

The Schlei is a shallow, approx. 43-km long fjord which flows into the Kiel Bight of the Baltic Sea (Fig. 1). The investigation sites were Olpenitz, located near the mouth of the Schlei, and Missunde in the central Schlei (Fig. 1). Salinities as well as temperatures were measured during the investigation time from April to September. Salinities were between 12.8 and $14.5 \%$ in Olpenitz and 5.8 and $8.2 \%$ in Missunde: the extreme values
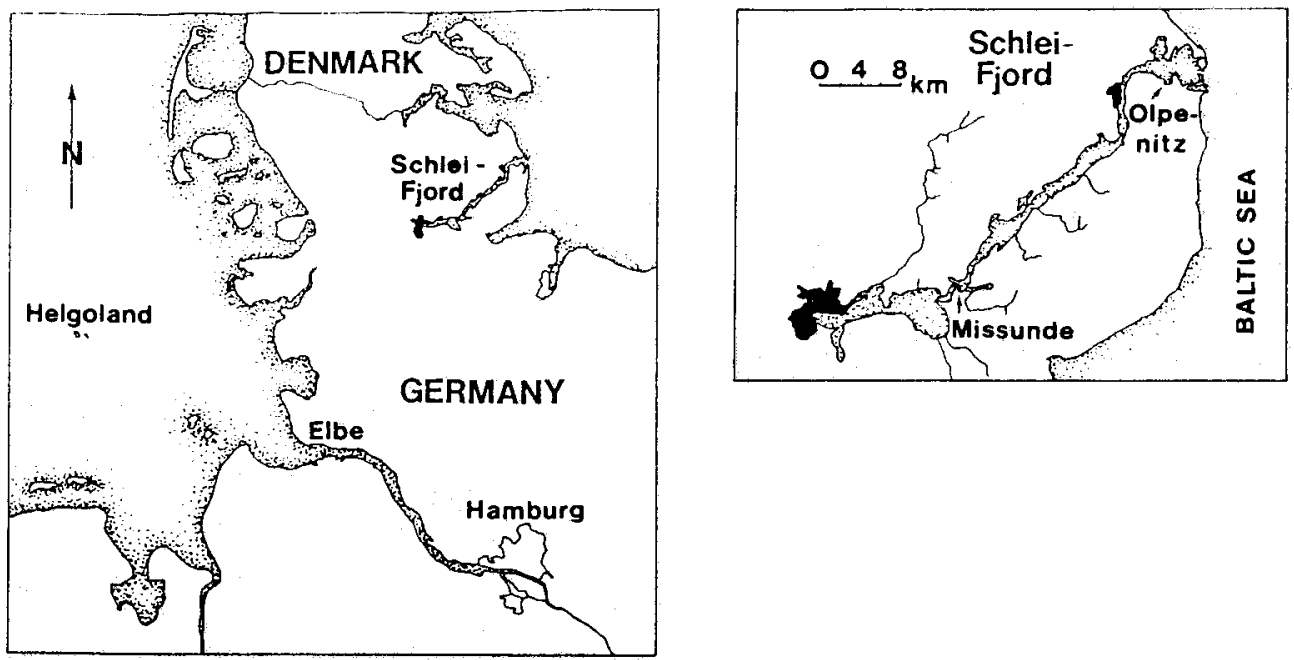

Fig. 1. Map of Schleswig-Holstein, Northern Germany, and an enlarged illustration of the Schlej fjord area showing the investigation sites of Missunde and Olpenitz

of temperature and salinity of both sites did not correlate. Temperatures increased at both stations from $9.5^{\circ} \mathrm{C}$ in April to 21 or $19.5^{\circ} \mathrm{C}$ in August, thereafter decreasing (Fig. 2).

Samples were taken monthly from April to September, 1991. The plankton organisms were obtained by pouring $100 \mathrm{l}$ water through a net of $55 \mu \mathrm{m}$ meshsize. The epibenthic crustaceans were caught by means of hand nets of $300 \mathrm{~mm}$ width and of $5 \mathrm{~mm}$ meshsize; each capturing period lasted $30 \mathrm{~min}$. Only in Olpenitz was additional sampling of Fucus-dwelling fauna, phyton, possible by covering the algae with a large PE-box which was then lifted out, together with the surrounding water.

A total of more than 36000 crustaceans was investigated (Table 1). The epibenthic and phytal organisms were identified and dissected for parasites under a stereomicroscope. Identification of the plankton organisms and of all parasites was done under a light microscope. In order to simplify the plankton analysis, a plankton-flow-counter was constructed (Gollasch, 1992) (Fig. 3): four glass slides were glued together with silicone, forming a counter box of $75 \mathrm{~mm}$ lenqth and $7.5 \mathrm{~mm}$ height with a hole in the middle. PE- 


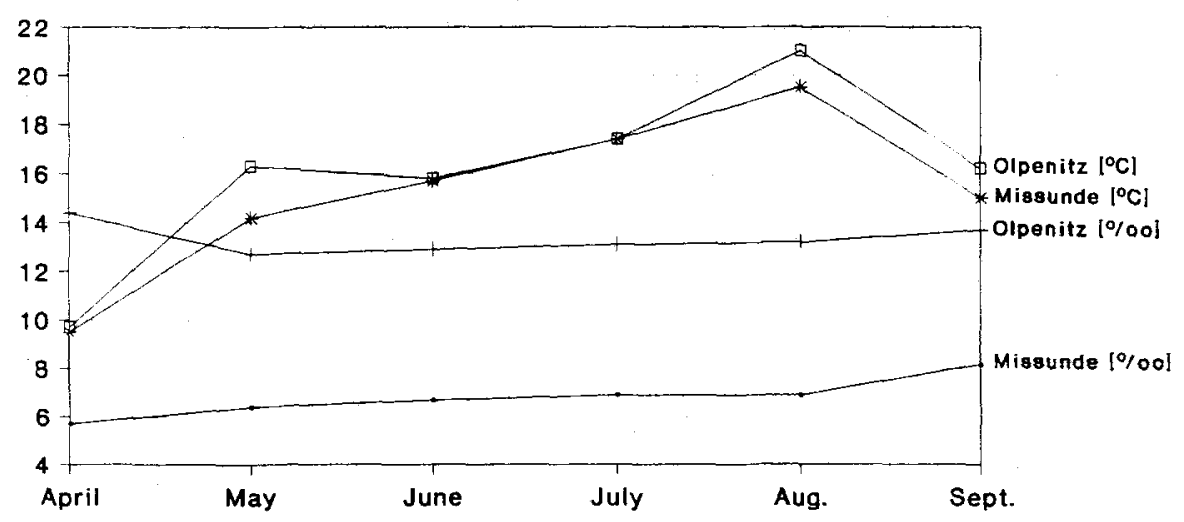

Fig. 2. Temperature and salinity values from the investigation sites of Missunde and Olpenitz during the period of April to September 1991

Table 1. Numbers of investigated crustaceans from the Schlei fjord

\begin{tabular}{|lcc|}
\hline Microhabitat and site & Individuals & Species \\
\hline Phyton Olpenitz & 2112 & 17 \\
Benthos Olpenitz & 602 & 17 \\
Benthos Missunde & 390 & 13 \\
Plankton Olpenitz & 8456 & 9 \\
Plankton Missunde & 25556 & 10 \\
without larval stages & & \\
\hline
\end{tabular}

tubes were connected with silicone to either side of the hole (Fig. 3). The plankton sample was led through the sloping tubes and the counter box which had been placed under a light microscope. The flowing speed was influenced by changing the height of the conveying tube and by adjusting a clamp on the lower tube.

The abundance of hosts was measured as numbers $1001^{-1}$ (plankton), numbers of 30 -min catches (epibenthos), and numbers related to $100 \mathrm{~g}$ dried Fucus (phyton). The

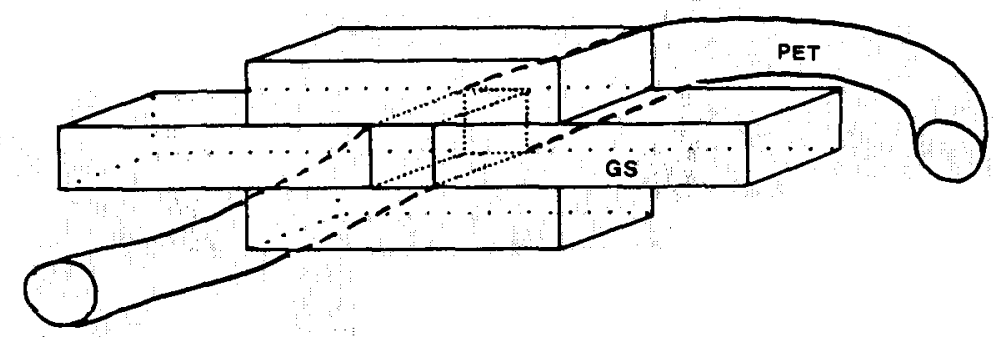

Fig. 3. Plankton-flow-counter construction consisting of four glass slides (GS) and two PE-tubes (PET) 
parasite parameters were abundance (mean number of parasites found in a host population) and intensity (mean number of parasites found in the infested hosts).

\section{RESULTS}

\section{Plankton}

The plankton comprised 7 (Olpenitz) or 8 (Missunde) copepods, respectively, 1 cladoceran, and 4 larval stages of copepods and balanids (Fig. 4). Centropages hamatus was only found in Missunde. Numbers were clearly higher in Missunde than in Olpenitz, which is especially true for Eurytemora affinis and nauplii. Maximal numbers were found in April/May. But Acartia tonsa, which is the only copepod species found in all months, showed higher densities in September (Fig. 4). Also copepod nauplii attained a second but far lower peak in September (Olpenitz) or August (Missunde). In contrast, the late summer season is more marked by the lowest frequency of the species and larval stages: only 6 in Olpenitz and only 5 in Missunde.

Cestodan larval stages were present in 3 (Olpenitz) or 4 (Missunde) copepod species, but only from April to June (Fig. 5). The parasite intensity was clearly higher in the hosts

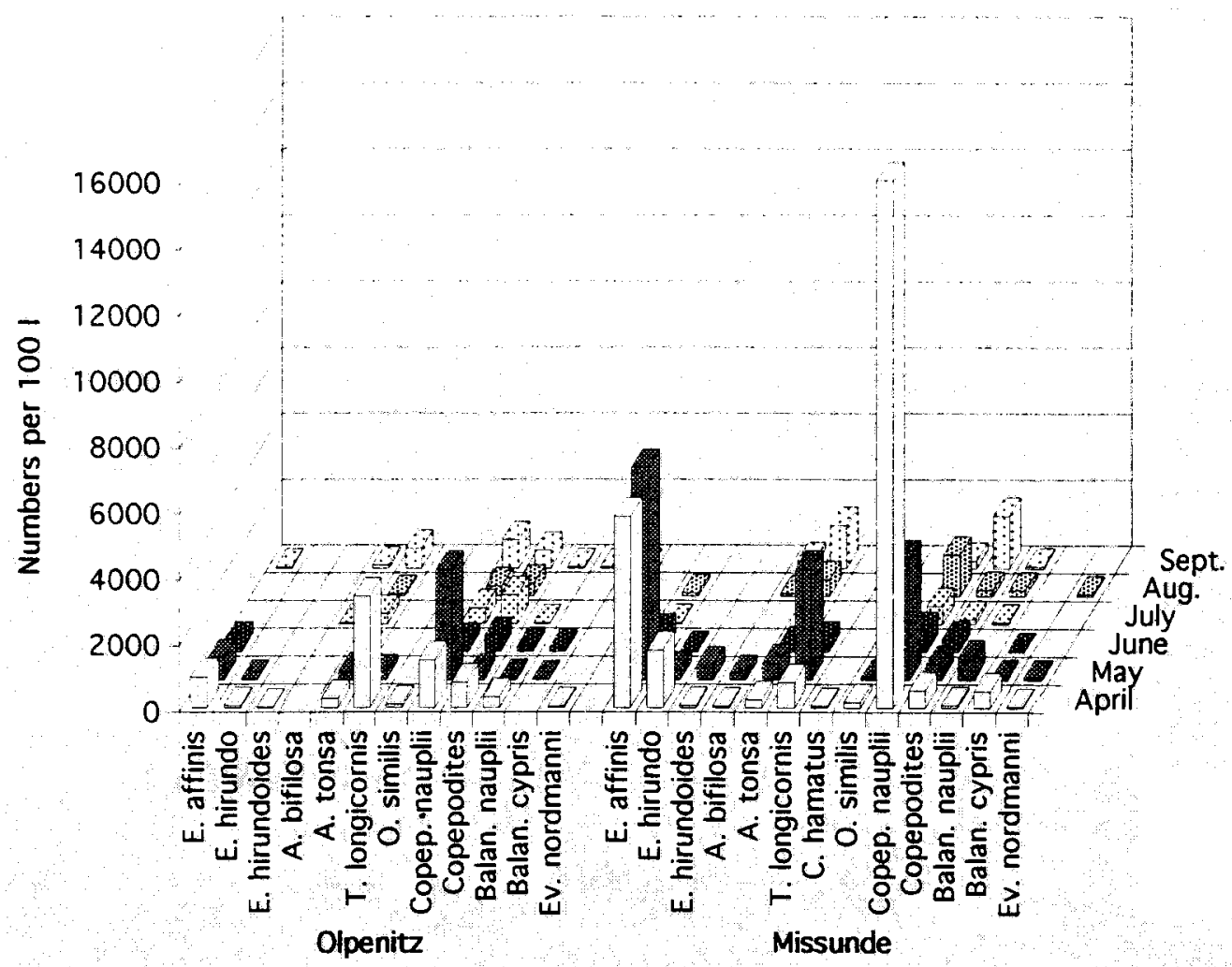

Fíg. 4. Dynamics (numbers per 100 ) of planktonic crustaceans from two sites of the Schlei fjord in 1991 


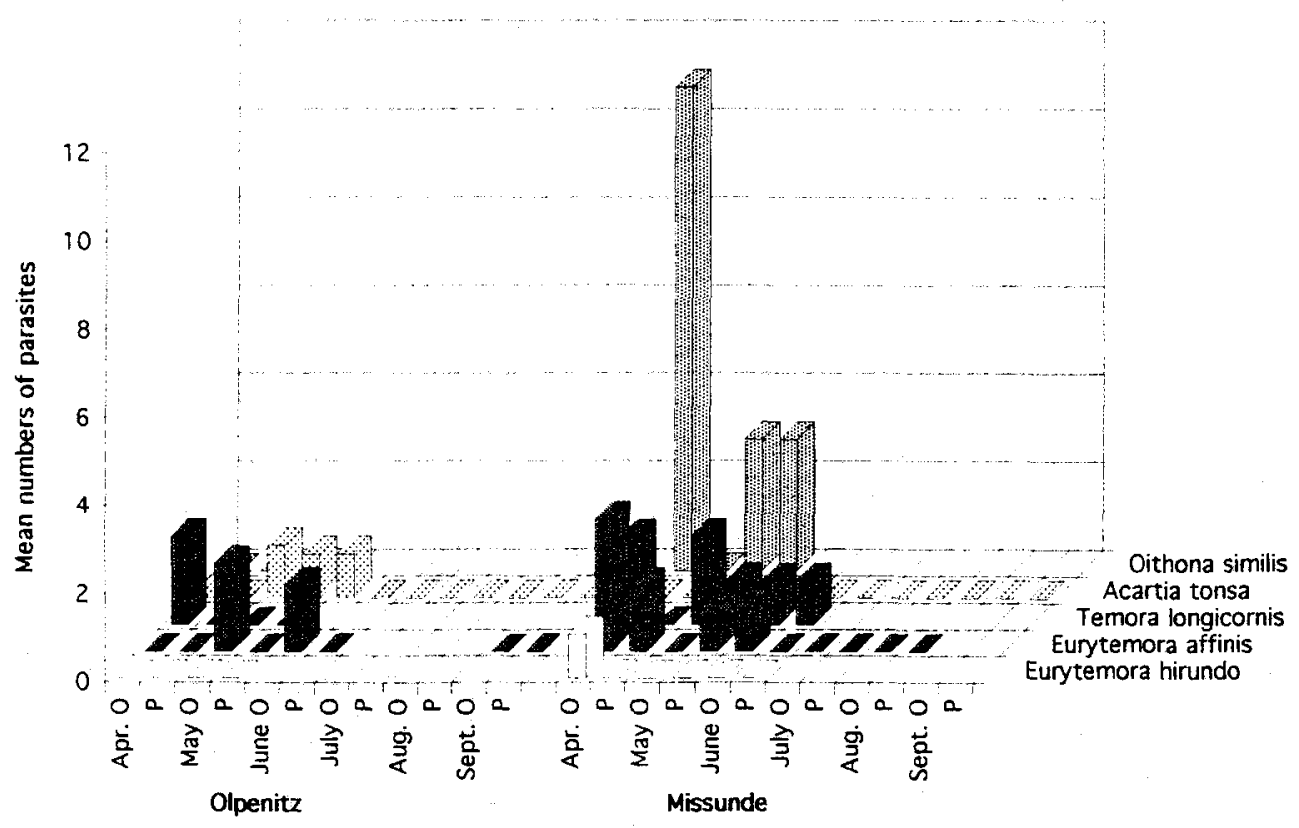

Fig. 5. Intensities (mean numbers per infested host) of cestodan larvae in planktonic crustaceans from two sites of the Schlei fjord in 1991. $\mathrm{O}=$ onchocercae; $\mathrm{P}=$ procercoids

from Missunde, where Oithona similis was the most important host. Whereas oncosphaerae were present in several copepods, only Arcatia tonsa harboured also procercoids in Olpenitz (Fig. 5). In Missunde, where A. tonsa was not parasitized at all, procercoids existed in Oithona similis and Eurytemora affinis.

\section{Phyton and benthos}

In Olpenitz the numbers of crustaceans were low in spring but increased in early summer; the phytal fauna was richest in late summer in contrast to the benthal fauna (Fig. 6). Whereas the Olpenitz samples comprised 8 species of importance, in Missunde only 4 were worth mentioning, with abundances far lower than those in Olpenitz. Gammarus locusta and Jaera albifrons were present during the whole of the six months in the Olpenitz phytal zone just as Crangon crangon was in the benthal zone and $G$. duebeni in Missunde (Fig. 6). Idothea chelipes dominated in the Fucus as well as in the benthal samples of Olpenitz, whereas Sphaeroma hookeri prevailed in Missunde. In the phytal fauna, Jaera albifrons was most abundant in spring, Microdeutopus gryllotalpa in early summer and Idothea chelipes in late summer. $I$. chelipes attained maximal numbers in the Olpenitz benthos by early summer, whereas Crangon crangon dominated in late summer (Fig. 6). In Missunde, higher numbers of Gammarus duebeni appeared first, followed by G. zaddachi and Sphaeroma hookeri.

The parasite spectrum comprised 8 species which were found in 17 crustacean hosts from the phytal and benthal zones. Table 2 offers evidence that the digeneans Maritrema 


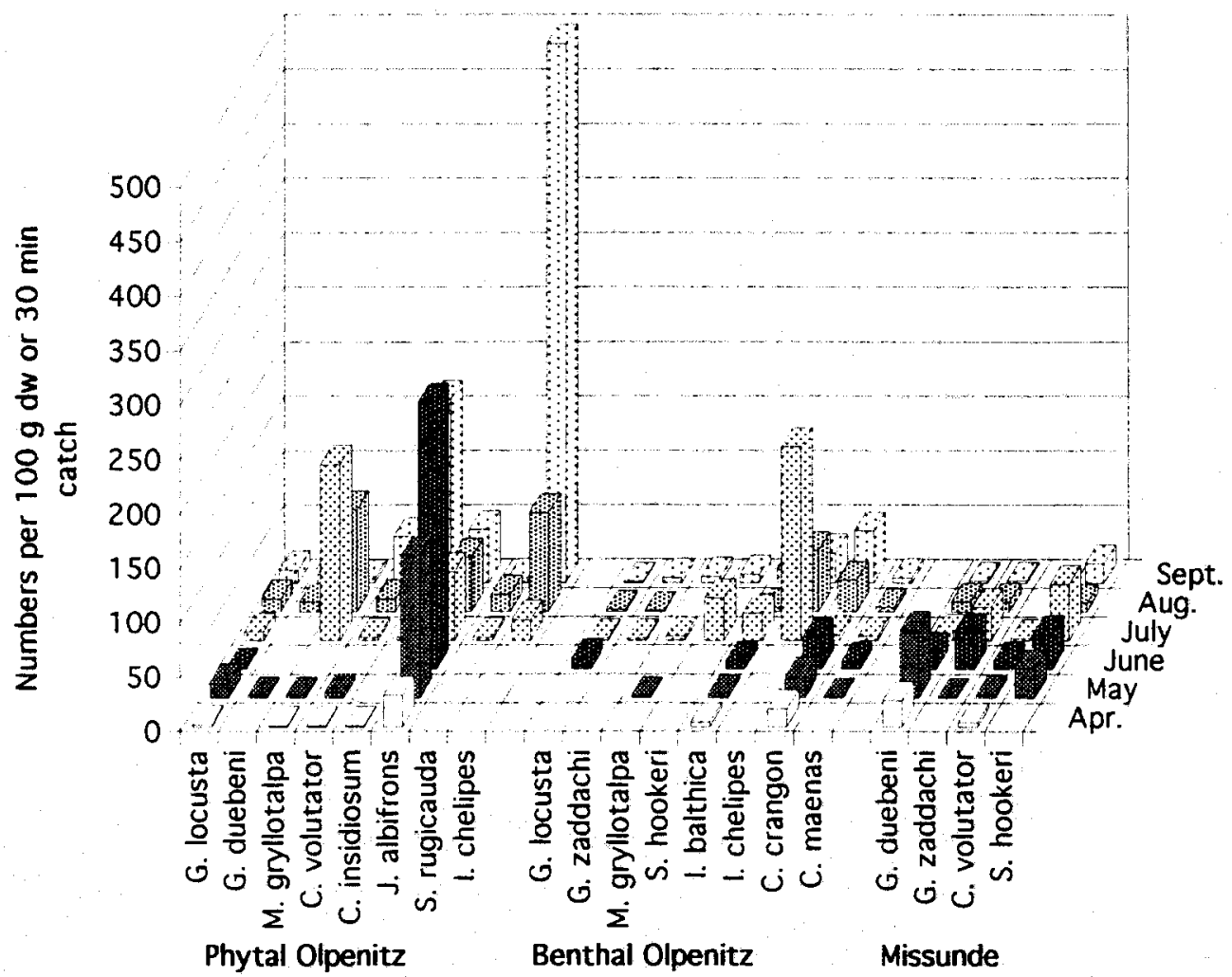

Fig. 6. Dynamics of phytal (mean numbers per $100 \mathrm{~g} \mathrm{dw}$ Fucus vesiculosus) or benthic crustaceans (mean numbers of 30-min catches) from two sites of the Schlei fjord in 1991

subdolum and Podocotyle atomon are the most frequent parasites therefore, the following analysis of parasite dynamics focusses on these two species.

Podocotyle atomon was not found in crustaceans from Missunde, which is explained by the absence of its first intermediate host, Littorina saxatilis, at this site. In total, 9 crustacean hosts were infested; infestation season was from June or July (Gammarus locusta only) until September (Fig. 7). Whereas in June/July mean abundances were highest in Idothea chelipes (2.5), and otherwise mostly about 0.5 , these values were very low in August/September. The mean numbers of parasites per infested host (the intensity) attained in Crangon crangon was as high as 8 (September) or 2 (July), in Idothea chelipes it was maximally 3 , and in I. balthica and Gammarus locusta only 2 (Fig. 7). The infestation of crustaceans began earlier and was more severe in the benthal zone than in the phytal microhabitat. This may be due to the absence of almost all potential hosts in the Fucus-belt in June, with the exception of Gammarus lucusta which is probably infested later.

Of the digenean family Microphallidae, Maritrema subdolum infested $92 \%$ of the crustacean hosts; Microphallus claviformis and $M$. papillorobustum were of lesser importance. In the Olpenitz samples, 11 crustacean species were infested, Corophium 


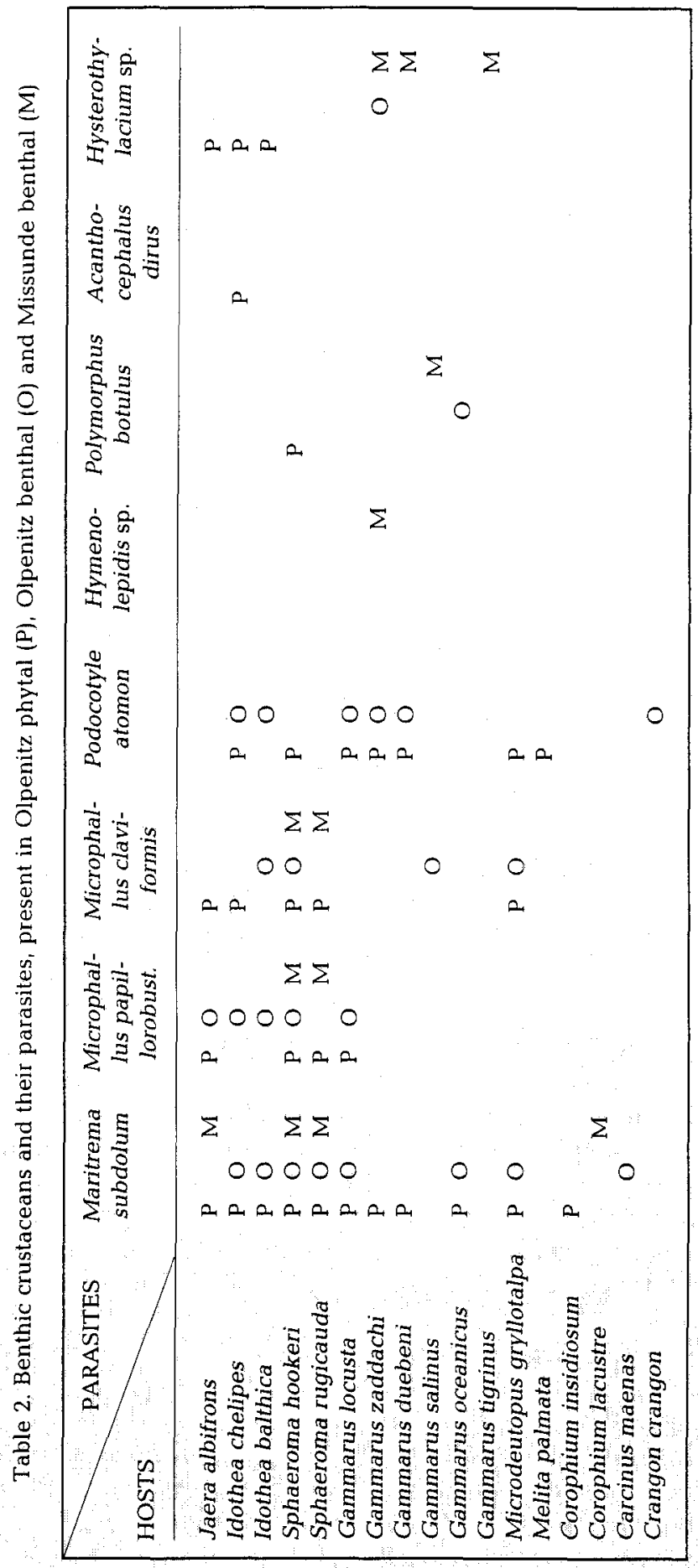




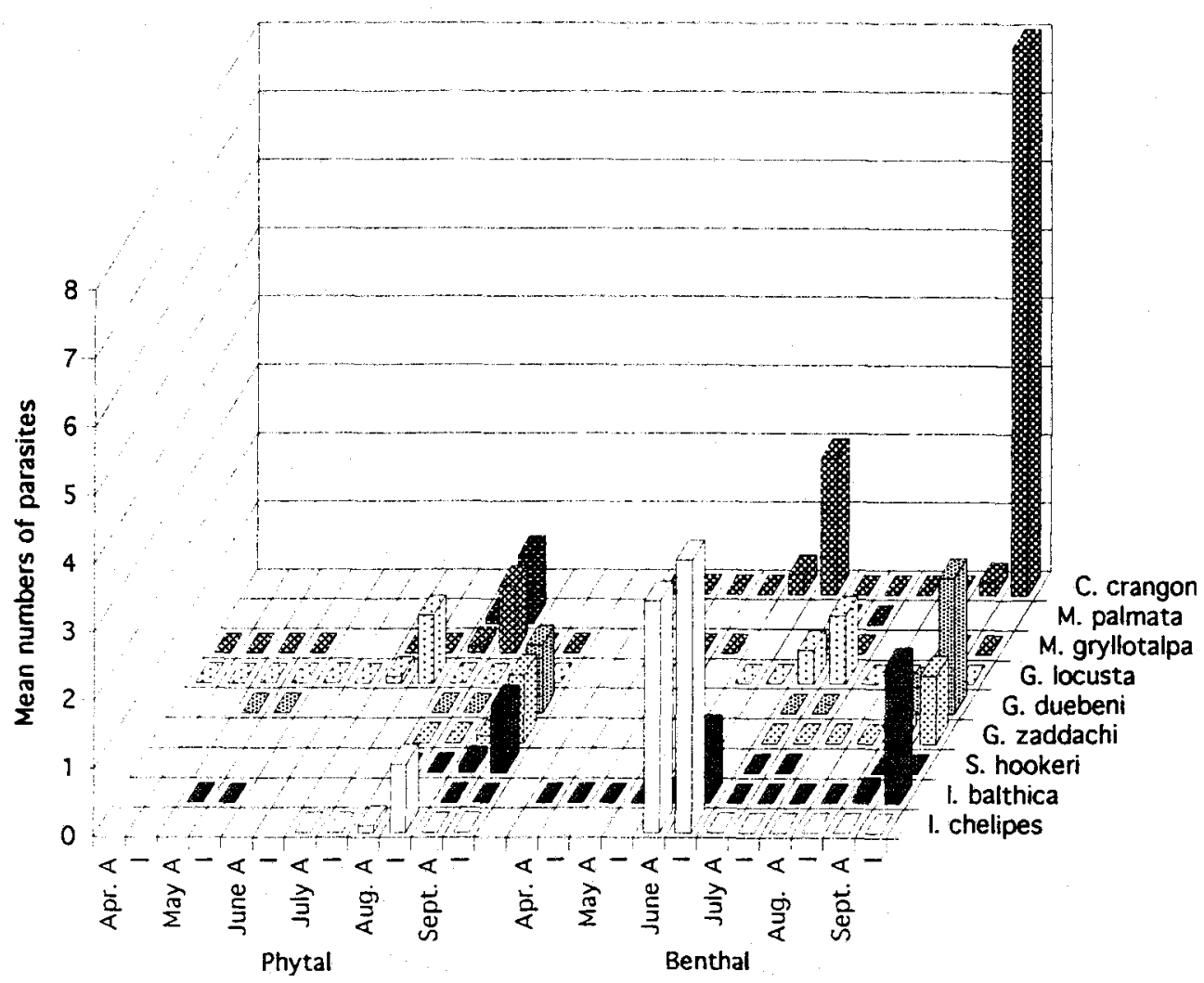

Fig. 7. Abundances and intensities of Podocotyle atomon in crustaceans of two microhabitats at Olpenitz 1991. $\mathrm{A}=$ abundance (mean number of metacercariae in the whole host population); $\mathrm{I}=$ intensity (mean number of metacercarieae per infested hosts only)

insidiosum was not present in the benthal microhabitat (Fig. 8). Only Idothea balthica harboured Maritrema subdolum in springtime already; other hosts were not infested earlier than July. Highest intensities and abundances were found in August in both microhabitats, the benthal system attaining higher values. The main host was clearly Idothea chelipes which was maximally infested in August by abundances of 24 and intensities of 34 parasite cysts. Generally, values in the phytal crustaceans were lower. Idothea balthica, Sphaeroma hookeri and Microdeutopus gryllotalpa were also important hosts (Fig. 8). In autumn, intensities and abundances decreased to a lower but still important level.

Only four crustacean species were infested by this parasite in Missunde, where Idothea species were absent. Therefore, other isopods, such as Jaera albifrons and Sphaeroma hookeri, became the most important hosts whereas Gammarus species were free of Maritrema subdolum cysts (Fig. 9). Corophium lacustre and especially Jaera albifrons were already hosts in early spring; these were replaced by Sphaeroma species which attained highest values in late summer. Generally, intensities and abundances present only a fraction of those found in Olpenitz (Figs 8, 9). 


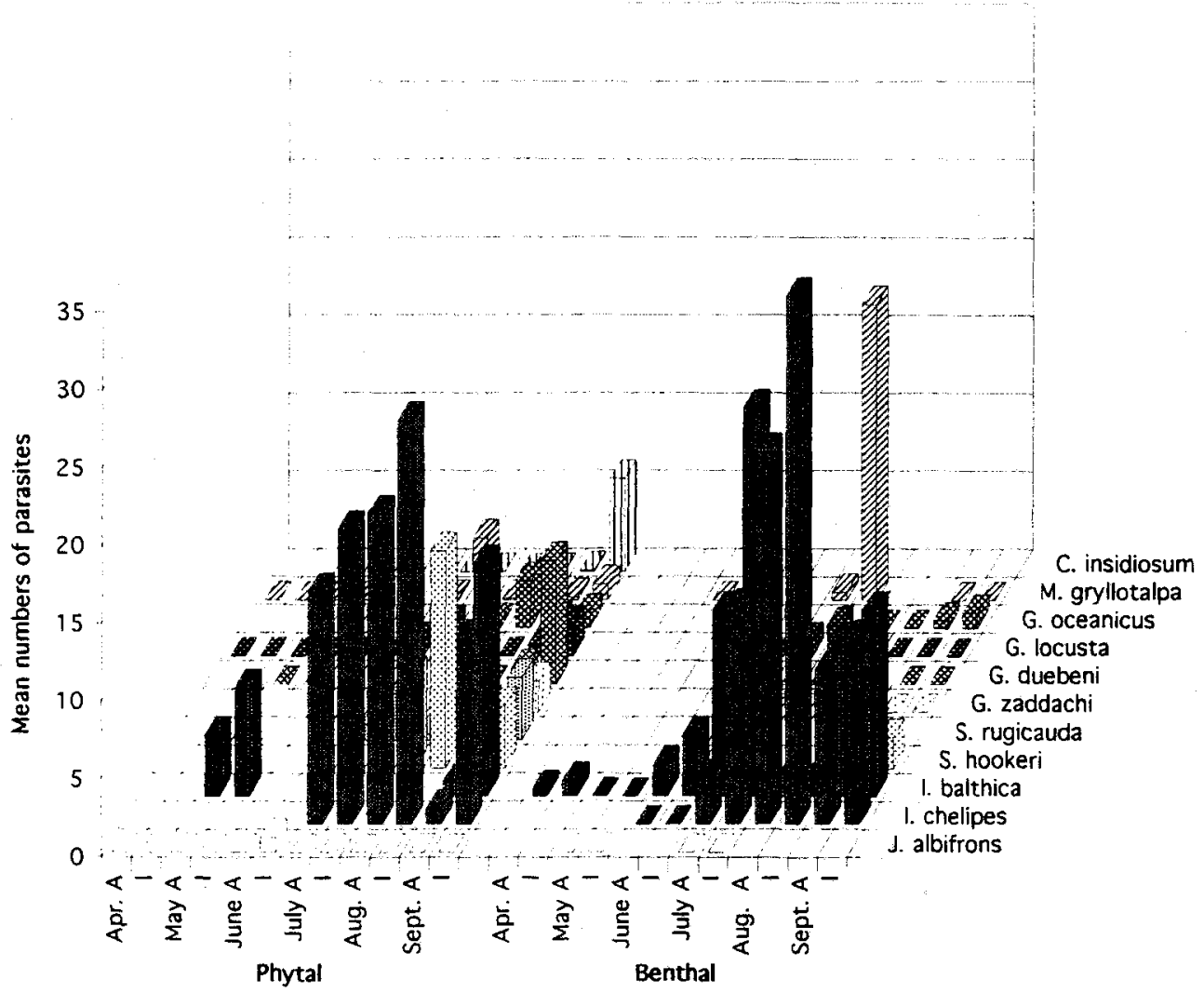

Fig. 8. Abundances and intensities of Maritrema subdolum in crustaceans of two microhabitats at Olpenitz 1991. $\mathrm{A}=$ abundance (mean number of metacercariae in the whole host population); $\mathrm{I}=$ intensity (mean number of metacercariae per infested hosts only)

\section{DISCUSSION}

The brackish-water rules of Remane (1958) could partly be confirmed by this study as far as crustaceans are concerned. The species minimum at sites of lower salinities, such as those as prevailing in Missunde, remains true for benthic but not for planktonic species. Unexpectedly, the density of benthic peracarids was higher in Olpenitz than in Missunde, whereas the planktonic copepods displayed larger populations in Missunde. In the Missunde benthos, organisms other than amphipods or isopods prevailed: harpacticoids, oligochaetes or chironomid larvae (Nellen, 1967; Zander \& Westphal, 1992). Among the plankton of Missunde, calanoids were even surpassed by rotifers (Lenz, 1970; Zander \& Westphal, 1992). The fluctuation of plankton copepods is influenced by the increase of fish larvae densities and their predatory activities (Schnack \& Böttger, 1981). The alternating peaks of Eurytemora affinis in spring and of Acartia tonsa in autumn were repeatedly renrded (Christiansen, 1988). Mites and harpacticoids were the domi- 


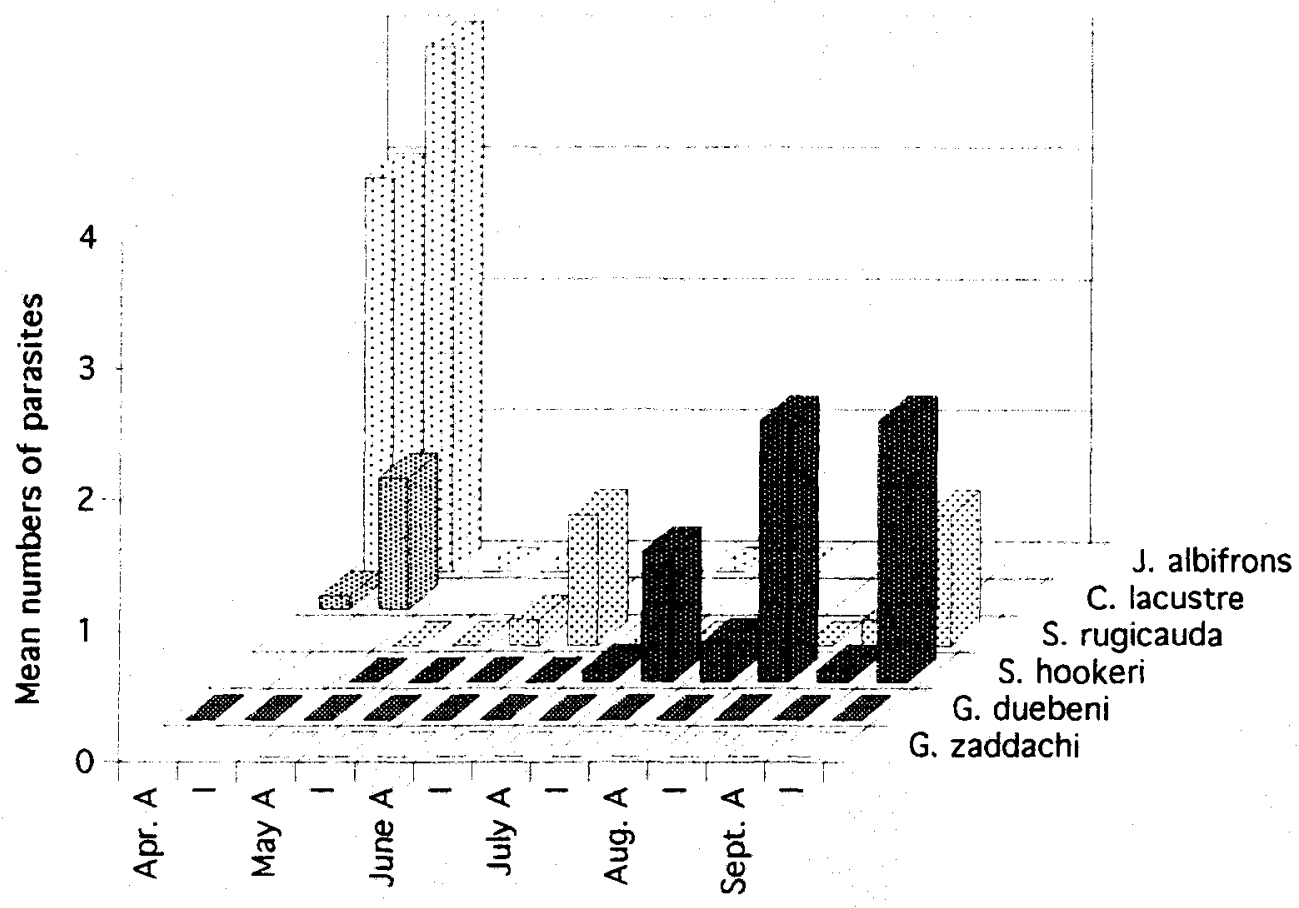

Fig. 9. Abundances and intensities of Maritrema subdolum in crustaceans from Missunde 1991. A = abundance (mean number of metacercariae in the whole host population); $l=$ intensity (mean number of metacercariae per infested hosts only)

nant groups in the phytal fauna of Olpenitz, but gastropods prevailed among macrofauna (Zander \& Westphal, 1992).

Whereas the cestodan larvae appeared at both Schlei sites in spring only, the results from the brackish Lübeck Bight presented high infestation rates in spring as well as in autumn (Zander et al., 1993). In this part of the Baltic, Acartia species were the most heavily infested, and Oithona similis the least heavily infested copepod, though the latter was the most abundant one. In very low salinities as in Missunde, these results seem to be reversed because Acartia tonsa harboured no cestodan larvae, whereas Oithona similis harboured the most. It is remarkable that infestation rates were higher in Missunde than in Olpenitz, which may be a consequence of species minimum. The cestodan species in question are Schistocephalus sp. and especially Proteocephalus sp. which are found in small-size fish of that area (Zander \& Westphal, 1991; Kesting, 1992). The seasonal differences of infestation may depend on the respective life-cycles of the cestodan species present in Schlei or Baltic Sea: for example, in the Lübeck Bight Bothriocephalus scorpii was found already in spring in its second intermediate hosts, gobiid fishes (Zander et al., 1993). This means that $B$. scorpii can reproduce in its final host, Myoxocephalus scorpius, in late summer, thereafter infesting copepods with its larvae.

Parasites of benthic crustaceans were found throughout the investigation period, albeit the appearance in spring of Maritrema subdolum was ensured by Idothea balthica only (Olpenitz). The main second intermediate host of this microphallid in Olpenitz was 
Idothea chelipes. Kreft (1991) found this isopod to be maximally infested not only in summer but even more severely in late autumn. The salinities which prevail in Missunde led to a general decrease of Maritrema subdolum abundances as well as to a host change. In consequence, true brackish-water crustaceans, such as Sphaeroma hookeri, seem to be more severely infested in lower salinities.

Podocotyle atomon, however, is restricted to Olpenitz because its first intermediate host, Littorina saxatilis, is absent in Missunde (Kreft, 1991; Kesting, 1992). Adult parasites were found in their final hosts, fishes, which were also caught in lower salinities due to migrations (Kreft, 1991; Zander \& Westphal, 1991; Kesting, 1992). Remarkable are the relatively high intensities of Podocotyle atomon in Crangon crangon which may emphasize a correlation of host size and numbers of parasite cysts in a single host. Size differences of cercariae also influence the intensities, because the large cercariae of Podocotyle atomon can only penetrate larger stages of crustaceans (Wendland, 1985; Zander \& Döring, 1989; Zander et al., 1994) and not small hosts, as can Maritrema subdolum.

Whereas Sphaeroma spp. and Gammarus duebeni are known to be true brackishwater species, the question arises concerning similar representatives among the parasites. The criteria must be higher abundances in lower salinities or in true brackish-water hosts. This situation was found in the digenean Cryptocotyle concavum and the gobiid fish, Pomatoschistus microps, which is second intermediate host (Zander et al., 1984). Some of the cestodan larvae studied in this investigation may be representatives of this group, but an exact determination was not possible. Hysterothylacium sp., probably $H$. auctum, was present in Missunde in Gammarus zaddachi in lower intensities than in G. duebeni which was not infested in Olpenitz, in contrast to G. zaddachi (Gollasch, 1992). As Hysterothylacium sp. seems to be very unspecialized in fish hosts (Zander et al., 1992), there is still a lack of sufficient data on the first intermediate hosts.

In conclusion, this study is able to give evidence of some coevolutive trends in hosts and parasites in extreme habitats such as brackish water.

Acknowledgements. We thank Dipl. Biol. V. Kesting who helped during the field investigations, Dipl. Biol S. Groenewold for help in the parasite determinations, also Prof. Dr. L. W. Reimer (Rostock) for additional advice in parasite taxonomy. Thanks are also due to Dipl. Biol. H. Kapp for critically reading a first draft of this manuscript, and to $C$. Berger for improving the English.

\section{LITERATURE CITED}

Berg, J., 1979. Discussion of the methods of investigating the food of fishes; with reference to a preliminary study of the food of Gobiusculus flavescens (Gobiidae). - Mar. Biol. 50, 263-273.

Christiansen, B., 1988. Vergleichende Untersuchungen zur Populationsdynamik von Eurytemora affinis und Acartia tonsa in der Schlei. Diss., Univ. Hamburg, $147 \mathrm{pp}$.

Esch, G. W., Shostak, A. W., Marcogliese, D. J. \& Goater, T. M., 1990. Patterns and processes in helminth parasite communities: an overview. In: Parasite communities: patterns and processes. Ed. by G. W. Esch, A. O. Bush \& J. M. Aho. Chapman \& Hall, London, 1-19.

Gollasch, S., 1992. Populationsdynamik und Parasitenbefall von Bivalvia, benthischen und planktischen Crustacea in der Ostseeförde Schlei. Dipl.Arb., Univ. Hamburg, 175 pp.

Kesting, V., 1992. Untersuchungen zur Parasitenfauna von Kleinfischen und Schnecken der Ostseeförde Schlei. Dipl.Arb., Univ. Hamburg, $183 \mathrm{pp}$.

Kreft, K A., 1991. Befalls- und Populationsdynamik ausgewählter digener Trematoden und ihrer Wirte in der Schlei. Diss. Univ Hamburg, $289 \mathrm{pp}$. 
Lauckner, G., 1992. Parasitenbefall der Strandkrabbe Carcinus maenas - ökologische Konsequenzen. - Jber. Biol Anst. Helgoland 1991, 25-27.

Lenz, J., 1970. Zooplankton. - Kieler Meeresforsch. 26, 203-213.

MacKenzie, K. \& Gibson, D., 1970. Ecological studies of some parasites of plaice Pleuronectes platessa L. and flounder Platichthys flesus (L.). - Symp. Br. Soc. Parasitol. 8, 1-42.

Nellen, W., 1967. Ökologie und Fauna (Makroevertebraten) der brackigen und hypertrophen Ostseeförde Schlei. - Arch. Hydrobiol. 63, 273-309.

Odening، K., 1974. Ontogenese und Lebenszyklus bei Helminthen und ihre Widerspiegelung in der Wirtsklassifikation. - Zool. Anz. 192, 43-55.

Reimer, L. W., 1970. Digene Trematoden und Cestoden der Ostseefische als natürliche Fischmarken. - Parasit. SchrReihe 20,1-144.

Reimer, L. W., 1983. Zur Entwicklung der Lebenszyklen bei digenen Trematoden und Cestoden. Wiss. Z. pädag. Hochsch. Güstrow (Math.-nat. Fak.) 21, 293-306.

Remane, A., 1958. Ökologie des Brackwassers. - Binnengewässer 12, 1-216.

Schmidt-Moser, R. \& Westphal, D., 1981. Predation of Pomatoschistus microps Krøyer and P. minutus Pallas (Gobiidae, Pisces) on macro- and meiofauna in the brackish fjord Schlei. - Kieler Meeresforsch. (Sonderh.) 5, 471-478.

Schnack, D. \& Böttger, R., 1981. Interrelation between invertebrate plankton and larval fish development in the Schlei fjord, western Baltic. - Kieler Meeresforsch. (Sonderh.) 5, 202-210.

Schriever, G., 1974. Die sessile, hemisessile und vagile Hartbodenfauna der Schlei im ökologischen Vergleich. - Kieler Meeresforsch. 30, 80-90.

Thienemann, A., 1939. Grundzüge einer allgemeinen Ökologie. - Arch. Hydrobiol. 35, 267-285.

Wendland, W., 1985. Über das Auftreten digener Trematoden und ihrer Zwischenwirte Schnecken, Crustacea und Kleinfische in der Schlei unter besonderer Berücksichtigung der Microphalliden. Dipl.Arb., Univ. Hamburg, 136 pp.

Zander, C. D., 1979. On the biology and food of small-sized fish from the North and Baltic Sea areas. II. Investigation of a shallow stony ground off Mon, Denmark. - Ophelia 18, 179-190.

Zander, C. D. \& Döring, W., 1989. The role of gobies (Gobiidae, Teleostei) in the food web of shallow habitats of the Baltic Sea. In: Proceedings of the 21st European Marine Biology Symposium. Ed. by R. Z. Klekowski, E. Styczyńska-Jurewicz \& L. Falkowski. Polish Academy of Sciences, Institute of Oceanology, Gdansk, 499-508.

Zander, C. D. \& Westphal, D., 1991. Kleinfischparasiten der Ostseeförde Schlei und ihre Einbindung in die Nahrungskette. - Seevögel 12, 4-8.

Zander, C. D. \& Westphal, D., 1992. Nahrungsbeziehungen von vier euryhalinen Kleinfischarten der Ostseeförde Schlei. - Zool. Jb. (Abt. Syst. Ökol. Geogr. Tiere) 119, 339-364.

Zander, C. D., Groenewold, S. \& Strohbach, U., 1994. Parasite transfer from crustacean to fish hosts in the Lübeck Bight, SW Baltic Sea. - Helgoländer Meeresunters. 48, 89-105.

Zander, C. D., Kollra, H. G., Antholz, B., Meyer, W. \& Westphal, D., 1984. Small-sized euryhaline fish as intermediate hosts of the digenetic trematode Cryptocotyle concavum. - Helgoländer Meeresunters. 37; 433-443.

Zander, C. D., Strohbach, U. \& Groenewold, S., 1993. The importance of gobies (Gobiidae, Teleostei) as hosts and transmitters of parasites in the SW Baltic. - Helgoländer Meeresunters. 47, 81-111. 